\title{
Journal of Infrastructure Development
}

\section{Attempting the Production of Public Goods through Microfinance : The Case of Water and Sanitation \\ Philip Mader \\ Journal of Infrastructure Development 2011 3: 153 \\ DOI: $10.1177 / 097493061100300204$ \\ The online version of this article can be found at: \\ http://joi.sagepub.com/content/3/2/153}

\author{
Published by: \\ @SAGE \\ http://www.sagepublications.com
}

Additional services and information for Journal of Infrastructure Development can be found at:

Email Alerts: http://joi.sagepub.com/cgi/alerts

Subscriptions: http://joi.sagepub.com/subscriptions

Reprints: http://www.sagepub.com/journalsReprints.nav

Permissions: http://www.sagepub.com/journalsPermissions.nav

Citations: http://joi.sagepub.com/content/3/2/153.refs.html

>> Version of Record - Jan 17, 2012

What is This?

\section{MPIfG Journal Article}

Philip Mader: Attempting the Production of Public Goods Through Microfinance: The Case of Water and Sanitation. In: Journal of Infrastructure Development 3(2), 153 - 170 (2011). Sage

The original publication is available at the publisher's web site: http://dx.doi.org/10.1177/097493061100300204

The MPIfG Journal Articles series features articles by MPIfG researchers and visiting scholars published in peer-reviewed journals. Max Planck Institute for the Study of Societies (MPIfG) Cologne | www.mpifg.de 


\section{Attempting the Production of Public Goods through Microfinance: The Case of Water and Sanitation*}

Journal of Infrastructure Development $3(2) 153-170$

(C) 201 I India Development Foundation SAGE Publications Los Angeles, London, New Delhi, Singapore,

Washington DC

DOI: I0.I I77/09749306 I I00300204 http://joi.sagepub.com

@SAGE

\title{
Philip Mader
}

Doctoral Fellow, Max Planck Institute for the Study of Societies, Köln mader@mpifg.de

\begin{abstract}
This article critically evaluates attempts to create public goods via microfinance loans in reference to the specific example of water and sanitation. The microfinancing of water and sanitation is a private business model which requires households to privately recognise, internalise and capitalise the benefits from improved water and sanitation. But household water and sanitation, being closely linked to underlying common pool resources, and being merit goods, have strong public goods characteristics and therefore depend on collective solutions. Two cases, from Vietnam and India, are presented and evaluated. Despite their dissimilar settings and designs, evidence is found that both projects encountered similar and comparable problems at the collective level which individual microfinance loans could not address. The problems encountered warn against an emergent micro-privatisation of water and sanitation through microfinance.
\end{abstract}

JEL Classification: O16, O18, Q25, Z18

Keywords: Microfinance, water and sanitation, public goods, Samuelson, cost recovery

\section{Introduction}

Microfinance in recent years has been heralded as a financial innovation in lending to traditionally uncreditworthy people which reduces poverty and promotes development. Microfinance commonly is merely the extension of financial services to poor people, focused on lending small sums for entrepreneurial purposes, but it is increasingly also understood as a means for promoting access to public goods such as education, health care and water for the poor. As an influential report prepared for the Gates Foundation proposed in 2008, '[m] icrofinance in many instances could help increase the level of service

\footnotetext{
*This article was presented at the Fifth International Scientific Conference 'Entrepreneurship and Macroeconomic Management: Reflections on the World in Turmoil', University of Pula, Croatia, in March 2011. I am indebted to two anonymous reviewers for their critical comments and helpful revisions.
} 
for individual households and for communities within a shorter time span than would have happened if these groups had to rely solely on public resources or their own savings' (Mehta 2008: 47). The idea here, espoused by NGOs and international development organisations, is that public goods could be paid for by the poor themselves via microfinance, instead of by transfer payments or facilitation via the public sector.

The assumptions differ as to how microfinance business models could substitute the public sector's role in providing public goods: sometimes microfinance institutions' (MFIs) ${ }^{1}$ lending is to be bundled with broader social service activities, at other times it is simply assumed that a certain social good is a by-product of microlending. Most often, the idea is that loans can be used by poor people to 'buy in' to services they otherwise could not afford. This extension of microlending to public goods is a natural extension of the original concept as espoused by the father figure of microfinance, ${ }^{2}$ Muhammad Yunus, given his conviction that 'government, as we now know it, should pull out of most things except for law enforcement, the justice system, national defense, and foreign policy, and let the private sector, a "Grameenized private sector", a social-consciousness-driven private sector, take over its other functions' (Yunus 2003: 204).

In this article, I examine this relatively recent extension - or perhaps, radicalisation - of the microfinance concept, which seeks to direct credit beyond entrepreneurship towards enhancing or replacing the state's activity as provider of public goods. I draw upon an expanded definition of public goods to argue that there are problems from both a political and an economic point of view. Microfinance for public goods represents a micro-privatisation of these goods, in which the public sector is relieved of the responsibility to provide for the most disadvantaged citizens, which legitimates the status quo where the state serves the interests of the elites well, while neglecting the poor. Institutionalising a system of 'public provision for the rich, self-help for the poor' is objectionable, regardless of whether such models are economically viable. But furthermore, the shift to private access mediated via credit is economically problematic as well. I seek to show that private credit interventions cannot viably generate inclusive access to goods and services such as water and sanitation, and that a proper understanding of the theory of public goods and of problems of collective action raises severe doubts about the capacity of individuals or households (using credit) to fund the provision of these types of services on a market basis at all. This article focuses primarily on the latter economic arguments, in order to develop a theoretically and empirically grounded critique of the application of microfinance to public goods.

I proceed first by explaining the concept of microfinance in the context of the shifting transnational political economy of development, and in Section 3 I examine the characteristics of the water and sanitation sector against the assumptions which underlie proposals to use microfinance for providing public goods. I explain how the notion that water and sanitation could be expanded using private credit is based on an individualistic entrepreneurial approach, which ignores the public goods characteristics of water and sanitation and the related collective action problems, and I develop a critique based on those characteristics. In Section 4, I present empirical evidence from a field study in Vietnam and from my own fieldwork in India. These findings contradict the assumptions underlying microfinance proposals and point to problems of collective action and larger regulatory and institutional failures. I conclude with a statement on the human right to water and ways forward looking beyond the cost-recovery paradigm.

Journal of Infrastructure Development, 3, 2 (20I I): I53-I 70 


\section{Microfinance and the Shifting Political Economy of Development}

The developmental state has been in decline since the 1980s, and in the decades since, microfinance has occupied an increasingly central position in transnational development efforts. This shift from developmentalism to finance-based visions of development is embedded in a political economy of development increasingly focused on liberalisation, debt recovery, privatisation and reduced international development assistance. With at least US\$ 65.2 billion (MIX Market 2009a, 2009b), the global microfinance loan portfolio now exceeds the combined volume of the US, UK, German and French foreign aid budgets. ${ }^{3}$

Present-day microfinance comprises a range of financial services including small loans, savings and insurance for low-income demographics ('the poor'). But microcredit loans were the starting point of the industry, and remain its principal business model to date. These microloans are commonly understood as a means for fighting poverty by harnessing the entrepreneurial energy of the poor; they support fiscal retrenchment by supplanting social policies and transfer programmes with small finance aimed at encouraging the poor to undertake entrepreneurial activities (Weber 2006). In their sum, these activities are expected to create economic development through individual micro-entrepreneurship - a questionable expectation in the light of slow growth in countries like Bangladesh over the past three decades of intense microfinance promotion. In Bangladesh, the dream of microfinance, full 'financial inclusion', has been achieved, as a full 25 per cent of the entire population now have a microfinance borrower account (Gonzalez 2010), but the country ranks 129th out of 169 on the Human Development Index. In fact, conversely, in economically successful countries,

the microfinance model has played no role whatsoever. To the contrary, these countries have very successfully reduced poverty and have grown rich(er) overwhelmingly by using a range of state coordinated policy interventions, financial institutions and investment strategies that are not only the complete opposite of today's 'new wave' microfinance model, but also - and this is the rub for those in the microfinance industry that might argue for 'policy co-existence' - very likely to be undermined by the proliferation of microfinance and its prior claim over savings and other important financial resources. (Bateman and Chang 2009: 5)

The concept of microfinance as a tool for development is fraught with difficulties. They include problems within microfinance, such as the fungibility of loans, the limited entrepreneurial opportunities open to poor people even with loans (Karnani 2009), the lack of scale and transformatory impacts achieved by microenterprises, and predatory lending practices under conditions of competition. They also include the failure of microfinance to adequately challenge the structures of poverty, which include a lack of essential public services, the anti-developmental macro- and micro-economic environments of poor countries, and a highly polarised ownership of factors of production and intensely stratified social relations. While easier access to credit can act as a cushion for the vagaries of 'disciplinary neoliberalism' (Gill 1995), we learn from Harvey that the growing importance of finance tends to exacerbate instability and risk. 'The credit system is a product of capital's own endeavors to deal with the inherent contradictions of capitalism' (Harvey 1982: 239); albeit an ineffective one, since it first internalises and then exacerbates disequilibria and imbalances. It would be a mistake then to assume that microfinance itself is a stable business, or that it contributes to a stable and successful political economy of development in the long run. (For an in-depth critique of microfinance, see Bateman 2010.)

Journal of Infrastructure Development, 3, 2 (20I I): I53-I 70 
The achievements claimed on the part of microfinance look particularly questionable against the background of the (yet unresolved) microfinance crisis that began in September 2010 in Andhra Pradesh, southern India, triggered by a spate of client suicides which exposed predatory lending, market oversaturation, dishonest interest rates and coercive recovery practices (Arunachalam 2011; Taylor 2011). MFIs have proven their capacity to earn substantial profits; the ten largest MFIs in India, the world's biggest microfinance market, posted an average return on equity of 37.8 and 35.2 per cent in 2008 and 2009, respectively. But it is increasingly apparent from empirical studies that microfinance loans fail as a tool for economic and social empowerment — see Karlan and Zinman (2009), Bannerjee et al. (2009), or for a recent meta-study, Duvendack et al. (2011). Given the high interest rates which ensure accumulation by the financier, and the inbuilt incapacity of loans to achieve a more equitable distribution of factors of production, microfinance is not the 'modern Robin Hood' which some have claimed on its behalf ${ }^{4}$ but rather it supports inequalities. As Servet (2010: 12) elucidates,

[t]he neo-liberal accumulation system led to a deterioration of labour compensation in favour of capital, and for large sections of the population in several countries, the need to compensate this loss in purchasing power by resorting more and more to credit. In the case of micro-credit, there does not seem to be a monetary relationship of the type employer/employee type, and this could suggest that there is no exploitation of workers. [...] But all in all, the interest payments for the loans which enable production or exchange activities to be carried out, correspond to a levy on the income obtained through these activities. There is no capital/labour relation at interpersonal level. But as a whole, there is transfer from one sector to another.

Instead of a lack of entrepreneurship - the abundance of which any Indian street market amply testifies for-developing countries crucially suffer from an underprovision of public goods which are necessary for economic and social development. This underprovision ranges from roads and infrastructure like water and sanitation, electricity provision and irrigation, to education and health services. Despite its aforementioned questionability as a replacement for social policies, microfinance is increasingly explored as a tool providing public goods, and (with the exception only of roads) has been proposed as a means for achieving or improving the provision of all of the above. ${ }^{5}$

Underlying this notion is a paradigm shift noted by Reis and Mollinga (2009: 3): 'Due to the finance gap in the RWSS ${ }^{6}$ sector and the paradigm of cost-recovery, microcredit schemes have globally become a popular element of RWSS policies in recent years. ${ }^{7}$ We may understand this paradigm as favouring a micro-privatisation of public goods. It goes in line with Gill's understanding of the role of microcredit programmes, during Bolivia's neoliberal restructuring in the 1990s, as 'a low-cost substitute for public investment in health, education, and infrastructure' (Gill 2000: 146), which was congruent with the simultaneous privatisation of water supply (Olivera 2004). While utility privatisation (which is often presented as necessary for utility expansion) and microfinance previously went ahead as parallel but separate programmes, the new kind of programme, in which microfinance is proposed as the agent for water and sanitation expansion, represents the synthesis of both.

\section{Analytical Framework: Public Goods and Collective Action}

Given the tangibility and high visibility of the resources involved, water and sanitation can be understood as a crucial case for testing the assertion that tiny loans to households in developing countries 
could be a means for providing and governing the public goods which in almost all developed-country contexts are provided and/or strongly regulated by the public sector. I examine this assertion in relation to two specific projects using microfinance for water and sanitation, and present some of the first empirical evidence challenging it. First, however, it must be clarified how microfinance-based projects (falsely) evaluate household water and sanitation as private goods, and why they should in fact be evaluated as public goods. While advocates of microfinance for water and sanitation posit a private 'win-win' situation, I hold that key characteristics of these goods and services make their benefits difficult to reap privately for producers and consumers, and the exclusion of one user generates detriments for another. Put simply, the problem of the microfinance model for water and sanitation is that it treats these resources as if they were private goods, which they are not.

The central premise of microfinance projects for the provision of water and sanitation (as well as for education, health care, etc.) is that small loans from private MFIs can and will, given appropriate project design, act as a substitute for provision by the public sector. That premise is rarely made explicit in the literature, though it is evident in the underlying assumptions which have guided such projects since Varley (1995: 5), the first author to suggest microfinance for water, elucidated the premise in his arguments: 'Municipal or state-owned utilities are often inefficient, overregulated, and unable to supply even the formal sector with adequate services. Subsidies through tax transfers and foreign aid/borrowing are becoming more difficult to secure.' The public sector then is understood as by definition incapable, and aid and tax transfers will naturally decline over time, so private enterprises must take over.

Microfinance models promise to help extend access by 'leveraging market-based resources' (Mehta and Knapp 2004: 13) through the private credit system-privately provided through MFIs, privately used by households - which would offer poor people a supposedly welcome opportunity to finance their own access to water and sanitation themselves. Supporters of microfinance models routinely warn against public subsidies, for fear of 'crowding out potential private sector resources' (Mehta and Knapp 2004: 12; emphasis added). They posit that 'experience in microenterprise lending has demonstrated that cost recovery should be central rather than peripheral to the design of sustainable financing mechanisms' (Varley 1995: 3). Water projects are, therefore, supposed to build on the ostensible successes of MFIs at providing social value through private enterprise (Intellecap 2009), for which an enabling environment for private investment is identified as a prerequisite (Agbenorheri and Fonseca 2005: 13; Mehta et al. 2007; Mehta 2008).

In this model, MFIs are expected to realise the profit opportunities presented by specialised loans for water and sanitation, and the borrowers will eagerly take advantage of these loans as an entrepreneurial opportunity for their livelihood improvement. The service providers (of water, sanitation and credit) are expected to recover their costs from households which take on loans; the households, in turn, repay the loan principal and interest from the private gains which they receive from the utility provision. Microfinance-based approaches to the provision of water and sanitation thereby postulate a 'win-win' situation of financial benefits accruing to households, and profits accruing to suppliers of water and credit. The nexus of provision in these models is situated squarely at the local level, with organisations following explicitly business-oriented models of provision, and the burden of payment is situated specifically at the household financial nexus. No state or similar institution is present in the model. Households' investments in latrines and water connections are premised upon household decision-makers recognising the private benefits from clean water and sanitation, which should incentivise the household to take on debt now, in order to reap future returns.

Journal of Infrastructure Development, 3, 2 (20I I): I53-I 70 
Among the commonly assumed benefits for households are savings in medical bills, extra earnings due to better health, and time saved by female household members which is invested in productive activities, thereby raising household income. But for a household's investment to generate the returns from which loan can be repaid, these gains must all be recognised, internalised and capitalised (that is, turned into a money gain) privately by the household. If that is not possible, the household is likely to incur a financial loss, or not engage in the investment at all. As I show here, the non-private characteristics of the goods involved therefore confound the simple market-oriented approach. Benefits from non-private goods are often difficult to recognise (households must be aware of their full benefits from improved water and sanitation), cannot be internalised privately (the benefits are often well-spread, accruing far beyond the individual household), and can be difficult to capitalise (the gain may be of a non-monetary kind).

Household water and sanitation are not simply private goods. Mainstream economics traditionally distinguishes between four types of goods - private goods, public goods, club goods and common-pool resources - and treats the existence of public goods as an instance of market failure. Market-oriented rational behaviour of individual gain-seeking will not produce 'efficient' (i.e., desired) quantities of public goods, since all positive externalities cannot be priced into the goods by market participants. A decentralised system of decision-making therefore cannot optimally determine the levels of collective consumption (Samuelson 1954: 388), so resources with public goods characteristics will be underprovided, unless collective-action means are found. However, complicating such an economic analysis of public goods is the rarity of pure public goods in practice. Contrary to parsimonious economic theory, most goods actually lie on a continuum between public and private. As to where exactly the line between public and private goods runs, economic theory offers us only deceptively precise boundaries, which are defied by most real-world goods. As Samuelson himself pointed out, with reference to the 'classic' example of subscription-based television services,

the essence of the public-good phenomenon was not intrinsically tied up with the inability to 'exclude' consumers from some common service; [...] even if [...it were possible for] such exclusion to take place technically, we should still be faced with an instance of intrinsic increasing returns and that in all such cases there is an element of the public good dilemma. (Samuelson 1954: 81)

Non-excludability and non-rivality then are not only imprecise categories; they can also conflict with the social considerations and societal institutions which define what is managed as a private good, and what is actually commonly managed. This applies particularly to goods which constitute essentials of a 'decent life', or which have an intrinsic value and yield public benefits (Kaul and Mendoza 2003). Most goods can somehow be made excludable with technological advancement, just as most goods, when pushed to the extreme, become rivalrous. But by thinking in categories of excludable and nonexcludable, rivalrous and non-rivalrous, economics follows a mistaken distinction between public and private along the 'inherent properties' of a good. Rather, as Malkin and Wildavsky (1991: 355) argue, the true distinction is socially constructed, and public goods 'are public because and only because society chooses to put the goods in the public sector instead of the private sector.' For this reason, Kaul and Mendoza differentiate between 'basic' (non-rival or non-excludable) and 'actual' properties of goods: 'those that society has assigned to them'.

Instead of a clean and exclusive categorisation, which is impossible, we should recognise that household water and sanitation display somewhat contradictory characteristics. For instance, water in a household's tap is private, but in order to reach that tap it must be taken from a common source and transported

Journal of Infrastructure Development, 3, 2 (20I I): I53-I 70 
through 'club'-type piping systems. We should then recognise that water and sanitation show important basic and actual characteristics qualifying them for an evaluation in the very least as predominantly nonprivate goods. This is the case especially at a level of basic (i.e., minimum) provision.

There are several key arguments to be made for this. First, access to water and sanitation depends on and affects underlying common-pool resources, which require collective-action solutions for their management. Unregulated, uncoordinated private use will lead to collective action dilemmas where the resources are depleted. For instance, one household's water consumption via a private borewell drains the common groundwater resource, and similarly, one household's non-usage of adequate sanitation, engaging instead in open defecation, pollutes the resource (a 'public bad'). Second, supplying clean potable water and sanitation to (previously unsupplied or undersupplied) households represents a merit good, in that there are significant benefits for the general public from each additional household's access. For example, a household with access to clean drinking water and sanitary facilities is less likely to contract and spread water-borne diseases, a benefit which is shared with neighbours and the entire community. The gains for one household are larger when all gain. Third, given the network characteristics of water and sanitation systems, significant economies of scale are attainable only by inclusive access. Drilling borewells or laying water pipes to supply a single household is inefficient when compared to supplying an entire street or neighbourhood. It should, therefore, be undesirable to exclude certain households from the resource, even if they are unable to pay. The use of water and sanitation systems is not strictly rivalrous, since one user's access creates the conditions for the other's access. ${ }^{8}$

Microfinance enthusiasts, however, neglect such public characteristics. Davis et al. are among the few which even barely touch the issue when they note that 'preliminary results suggest that microlending may be an effective means of helping households in communities with existing trunk infrastructure to access improved water supply and sanitation services in their homes' (Davis et al. 2008: 5; emphasis added). But even they leave aside the question of where the trunk infrastructure should come from. Given the strictly private view taken by advocates of microfinance for water and sanitation, blindness for the systems perspective comes with the territory. The system is however the prerequisite for individual access. As Hall and Lobina (2006: 17) explain:

Water services depend on an extensive network of pipes, pumping stations, treatment plants, and reservoirs. As a result, a very high percentage of the cost of water systems is the cost of investments in this network, and so water is a very capital-intensive sector. Extending water services to all requires a lot of capital to finance the new networks, and it is very expensive. Those still needing connecting are poor, and the resources required to connect them cannot be provided by the poor themselves. There has to be distribution from those with greater incomes.

In microfinance-funded water and sanitation projects, there is explicitly no such distributionsubsidies are abhorred. By placing the onus on individual households to recognise, internalise and capitalise the benefits, and asking them to individually take the decision to invest, microfinance projects for water and sanitation provision neglect the above-described collective-action aspects. In such projects, the duty to take a loan for the purpose of investing in water and sanitation falls squarely on the individual household, which on its own is expected to realise a financial incentive for water and sanitation upgrading. The two case studies in the following section demonstrate that, in practice, the private aspect of microfinance projects for water and sanitation conflicts in a number of ways with the collective level on which project success depends. 


\section{Evidence from Vietnam and India}

In this section, first I discuss the findings made by Reis and Mollinga (2009) in Vietnam. I then follow with my own findings from fieldwork conducted in the Indian state of Andhra Pradesh between January and July 2010. At present, these are the only two known empirical social science studies of cases in which microfinance was used for water and sanitation. The particular combination of these cases permits a logic of maximising variation, as two very dissimilar approaches in applying microfinance to water and sanitation are studied; the cases differ on key dimensions. As elaborated below, the Vietnam programme used credit from a state development programme funded by public-sector donors in rural areas. The programme was implemented in the context of a statist economy through state-organised local committees. The Andhra Pradesh case, on the other hand, used credit from private MFIs complemented by funding from an international private philanthropic source in an urban and peri-urban setting. The project was implemented in a relatively liberal market economy setting through NGO-organised women's self-help groups (SHGs). Both cases, however, had households individually making the decision whether it was in their best interest and within their financial means to undertake the proposed improvements. ${ }^{9}$

These cases differ in some ways, as any real case may be expected to, from the model set up in theory, which I outlined in Section 3. Neither case represents a 'pure' application of the microfinance model for water and sanitation, and in my exploratory research I could find none operating anywhere in full accordance with the theoretical model. The cases in Vietnam and India both depart from the model especially in respect to full cost recovery and the stipulation of exclusive private-sector activity. Both programmes were subsidised in different ways and partially depended on non-market actors, such as NGOs and public bodies, for their implementation. The findings presented below should, therefore, be read in light of the fact that the pure, market-only model was not applied in its full severity. On the basis of the discussion in the previous section, the collective action problems discovered in both cases should expectably be exacerbated, if the subsidies were removed and the provision restricted to private water and sanitation providers.

\section{I Vietnam}

In the southern Vietnamese district of Can Tho, Reis and Mollinga (2009) found catastrophic sanitary conditions, since most rural and peri-urban households used the same rivers and canals for sewage disposal on which they traditionally depended for drinking and domestic water. They especially used these as water sources during dry season. Pesticides and industrial waste additionally contaminated the watercourses, and households used a mix of piped water (where available), rapidly depleting wells, rainwater, river/canal water and some other minor sources. Many households living in areas with piped water supply could not afford the administrative and technical costs of a connection, especially since the rural setting incurred a high materials cost for pipes from the mains to the house; costs which the water board would not cover.

In a project begun in 2004, microloans of a low nominal (negative real) interest rate were channelled from the Vietnam Bank for Social Policies (VBSP) via local credit groups to households seeking to upgrade their water and/or sanitation facilities. The predicted full costs of the various latrine options were between 40 and 160 euros - which in practice constituted the available loan sizes, though

Journal of Infrastructure Development, 3, 2 (20II): 153-170 
households complained that the costs were actually far higher - in an area where the monthly per capita poverty line is at 8 euros. A total of 23,109 constructions were implemented. Originally, the programme ran into a lack of demand from its intended beneficiaries, as local representatives reported, but households eventually began to emulate uptake from a few first-movers. Local perceptions of modernity and progress played an important role in this outcome.

The project managed to somewhat increase rural sanitation access, though only the most expensive $(160+$ euro) type of latrine, which included a septic tank, was constructed. Cheaper options were not perceived as an improvement over traditional systems by households, specifically over the 'fish pond' toilet, which ultimately polluted common waterways.

The factor 'modernity' is a major incentive for rural households regarding the construction of a new latrine. [...] Having a septic tank latrine plays the role of a status symbol, which a simple latrine model cannot fulfil. This is also illustrated by the term 'beautiful latrine', which was often used by interviewees to describe their new toilets, and by the pride with which households presented them. (Reis and Mollinga 2009: 13)

The question of long-term sustainability was, however, not addressed, as the researchers found that households and officials were oblivious or indifferent to the fact that septic tanks would have to be emptied within 10 to 20 years, which at present was technically impossible (except by hand) due to the narrow roads in the area. It also appeared that the implementation only of the more expensive schemes excluded poor households, and thereby the project did not create the intended level of impact. Poorer households were mostly precluded from access to credit through group exclusion and through selfexclusion (non-demand), and were dissuaded by the high-cost technology.

The largest share of the budget is used by households which construct septic tank latrines. These households usually have access to tap or well water, because the latrine requires "plenty of water for flushing" (according to $\mathrm{MoH}$ decision 08/2005). It was not observed that any of these households did not have access to tap or well water. This also indicates that the programme mainly reaches medium-income and better-off households, for which clean water supply is mostly not problematic. (Reis and Mollinga 2009: 18; emphasis added)

On the water side, Reis and Mollinga were presented with a mystery. Despite the project's aim to also increase piped water access and the presence of water filtration, no new water connections were to be found. Some wells had in fact been dug, but despite a specific condition prohibiting this within the project, so as to prevent further groundwater depletion; but there were no new taps or household water filtration systems. An effective and relatively affordable (approximately 100 euros) household water filtration system for contaminated water, which had been locally developed and which was intended for roll-out through the project, was not used. Local officials and project authorities explained the lop-sided emphasis on sanitation as resulting from greater demand for latrines, claiming that access to clean water was already widespread; however, Reis and Mollinga found this not to be the case. Instead, they found the redirection of water loans toward sanitation to be aligned with the business interests of local construction firms that arose during the liberalisation of the Vietnamese economy. Key figures in water supply companies were simultaneously the owners of construction companies for centralised purification systems. The authors note, 'it is to be seen in this context that the interest of government agencies, as well as officials as private persons, are highly interwoven with the business interest of private enterprises that are contracted to carry out public tasks' (Reis and Mollinga 2009: 17). 


\subsection{Andhra Pradesh}

The findings presented below are from field research on a project in Andhra Pradesh (AP) in southern India. ${ }^{10}$ This research — which consisted of participant observation over several months and of 29 semistructured interviews with SHG members, NGO workers, municipal officials and academic expertswas conducted in the spring and summer of 2010, immediately before the advent of the microfinance crisis which began in September 2010. The findings only roughly connect with those recent events, but should be considered against the background of the over-indebtedness and predatory lending patterns which have since become better-known. In hindsight, for instance, the fact that several SHG women reported having multiple loans from MFIs as well as moneylenders should have been explored more deeply, as it would have helped to bring into focus the relationships between microfinance (including microloans for water and sanitation) and debt stress. However, at the time of the research, I could not foresee the events which would unfold a few months later.

The project was begun in 2009 as a pilot in three sites: two medium-sized rural municipalities of between 130,000 and 200,000 inhabitants, and one large municipality of nearly 900,000 inhabitants on the outskirts of Hyderabad, the state capital. Groundwater in AP is rapidly depleting; Hyderabad, for instance, has had to enhance its own supply with a massive inter-basin transfer scheme over 120 kilometres length, with a lift of 400 metres. One of the two smaller towns lies in a coastal floodplain where groundwater is (naturally) contaminated with fluoride which causes bone and joint disease (expert interview, 25 May 2010), and the other lies in the driest region of southern India, which has been highly raindeficient in recent years. Especially in the smaller towns, people regularly suffer from throat infections, jaundice and diarrhoea as a result of unsafe tap water (interview with NGO worker, 17 February 2010); and in Hyderabad in 2009 fourteen people died from E. coli spread through the municipal water supply (Times of India 2010).

The project targeted poorer underserved areas within the three municipalities. All three municipalities have experienced rapid growth in recent decades; the Hyderabad suburb even more than doubled its population in the past 10 census years. The municipalities are still trying to catch up with the water and sanitation needs projected for in the 1990s (interview with a Municipal Commissioner, 2 July 2010). They do not supply poor areas reliably with water. Many parts only receive water for half an hour or one hour every other day, or even less, via on-street public taps which are widespread but not present in all neighbourhoods; some neighbourhoods are only supplied by water tanker.

The project consisted of three distinct elements: (a) household water tap connections, (b) household sanitary latrines and (c) communal drinking water from Reverse Osmosis (RO) plants. Funding came via a grant from a large American foundation, which gave a subsidy of approximately 80 euros to cover half of the estimated construction cost of a latrine or water connection. The other half came from sundry microfinance providers - MFIs, banks and informal moneylenders - or own savings (which households rarely had). The subsidies were disbursed by a regional NGO working with women's self-help groups (SHGs). Membership was a criterion for household participation, and SHG Federations consisting of elected representatives of 20 to 40 SHGs acted as financial intermediary and organisational nexus. Officially, the role of the NGO was only 'capacity-building', though in practice its employees' functions included project co-ordinator, training provider, financial auditor and whenever necessary, social discipliner-in around 25 per cent of SHG Federation meetings I attended, the (male) NGO workers publicly disciplined the (all-female) SHG representatives for various laxities and oversights, and sometimes withheld funds. The project was furthermore given some infrastructural and financial support by

Journal of Infrastructure Development, 3, 2 (20II): 153-I 70 
the state government's urban development programme, MEPMA. ${ }^{11}$ On the whole, it was a complex project set-up which represented a certain amount of social re-embedding of the microfinance idea.

Through the project, 5,613 constructions were to be implemented, at the time of my research. Averaged over the three sites, 44 per cent of eligible non-served households had come forward for the project's latrine subsidy, and 33 per cent for the water tap subsidy. As the project's director explained to me, the improvements were premised on people's self-identification of their need.

So we asked the community: if you need it, and you also recognise the importance, then you pay 50 per cent, it is an asset for you. Otherwise you can also build fully through your funds. So now, this is the opportunity to build your own asset at 50 per cent, the remaining 50 per cent come from other sources. (Interview, 16 February 2010)

At the time of my research the project was far behind its own schedule. Of at least eight communal RO plants planned, only three had been built and were operational; the foundations for two others existed, but were at least temporarily abandoned. The RO plants were funded 50 per cent by the American foundation and 50 per cent by the state development agency, MEPMA. Two of those which were operational had attracted a growing number of several hundred households who regularly came to purchase $12 \mathrm{~L}$ cans of drinking water for approximately 0.04 euros each. The RO plants represented something of a communal enterprise offering employment for several SHG ladies as attendants, earning a monthly wage between 32 and 48 euros under the direct supervision of the SHG Federation. For the purposes of this article, it can be noted that these RO plants provided an apparently valuable service to the community, albeit without any involvement of microfinance. Even so, the majority of planned RO plants was stalled; two were stopped due to local political contentions. Elected leaders of other backward castes (OBCs), who were not included in the project, had blocked the construction of one plant ${ }^{12}$; evidently, the local leadership had been bypassed. In another town, a political party was blocking the construction of an RO plant in one of 'its' neighbourhoods for as long as the rival party ruled the municipality. Infrastructure projects in India are invested with high prestige for political figures, and it appears that the political realm is key for success or failure.

As for the household water and sanitation improvements, a year after demand appraisal, merely 11.7 per cent of the approved 2,925 household water connections and 9.7 per cent of the 2,688 sanitary facilities had been provided. Note here that 'provision' refers not to delivery of a product but to full disbursement of the 50 per cent subsidy - the household must complete part of the construction before half of that subsidy is disbursed, and finish the sanitary works and the roof before the other half is disbursed. During site visits, only a relatively small number of constructions were actively in progress, and some completed toilets were not being used; households were not comfortable using them yet, it was said. It was explained (mystifyingly) that they were not perceived as 'completed' before a plaque with the name of the NGO and the funders had been attached. A number of facilities were being used as storage space. Many toilets had been integrated into new extensions or additions to the house, perhaps in line with the idea of locally adapted 'assisted incremental housing' espoused by John Turner (1976), but the aspect of modern sanitation often seemed to be of secondary importance.

It is possible to identify several causes for the slow progress and low uptake. They include the limited financial capacities of the intended beneficiaries to undertake investments (even with a subsidy and a loan), as well as an occasional lack of space, or space use restricted due to vastu shastra ${ }^{13}$ principles. Additionally, there was a lack of secure land use rights, since land was formally squatted, and tenants of 
rented dwellings naturally declined to invest in their landlord's house. The households were expected to obtain loans for their 50 per cent cost contribution, and crucially it was found that most had no trouble accessing finance. Almost all reported having microfinance loans, while many had several loans both from formal and informal sources (a finding which, in hindsight against the microfinance crisis, should have been more deeply explored). Given this existing access to finance, evidently, few would have undertaken water or sanitation construction without the subsidy or the proposition through the projectloans were available before, but were not used for water or sanitation.

Several structural constraints to household water and sanitation lay at a higher level than households' access to finance. In this sense, the 'blame' for a possible non-completion of the project's interventions would not lie with any of the project's implementing agents, but with the basic premise that household access to finance was the key constraint. Water taps in fact depended crucially on the capacity of the municipal water board to deliver more water, which it usually could not. NGO workers regularly and positively interacted with municipal officials, who were open to their suggestions and needs, but were constrained in their capacities. The underlying problems could not be tackled by the small loans; at best they were moderated for those who happened to be in reach of existing supply systems.

Where taps were being provided, they were only demanded by 38 per cent of households, of whom 17 per cent had completed their part in one year. Many households apparently saw no improvement in having to pay around 1.60 euros per month for the same irregular and insufficient water service as was (usually) available from public taps on the street; those who did were building storage tanks on their property at additional cost, to collect water from their tap whenever it would come, for later use. In one town (in the dry region), no tap connections had been provided at all; this town was constructing a large new storage reservoir, after which taps might also be provided there. These issues are symptoms of a long-term underinvestment in water and sanitation in India, exacerbated since liberalisation, as well as an inequitable distribution of the available resources (interview with town planner, 19 February 2010). This is most starkly seen in Hyderabad, where upscale neighbourhoods benefit from sufficient and sufficiently reliable water provision, as does a Coca Cola bottling plant on the outskirts, but entire peripheral areas have irregular piped supply, or no piped supply and must be supplied with tankers, if at all. ${ }^{14}$

The two smaller towns both have no sewer system, so any sewage must end up in private septic tanks. Municipal officials considered a sewage system an important investment, but said it was far beyond their towns' financial means (multiple interviews). In greater Hyderabad, the sewer system does not extend to most poor neighbourhoods; therefore, usually septic tanks would be constructed here, too, although in a select few target neighbourhoods, the toilets are connected to pre-existing mains pipes. As in Vietnam, no arrangements had been made for emptying the septic tanks at a later stage. NGO workers did not know how long it would take until tanks would have to be emptied, nor did they know how it would be organised when the time came. 'They [the beneficiaries] will take care of it then and maybe they will take a loan' (interview with NGO officer, 20 June 2010).

It is interesting to note the motivations of the households who applied for the sanitation subsidy, which were usually at odds with the theory that households will undertake sanitation upgrades as an investment in their health. Rather than pointing to diseases (which were rarely mentioned), the interviewed SHG members repeatedly named three concerns about their present sanitary situations. Two of these were directly linked with local social codes compelling women to go for open defecation at night: fear of wild animals (especially snakes) and of rape (circumscribed as 'drunken men' or 'dangerous fellows'). The third concern was the increasing pressure from urbanisation, this being especially marked

Journal of Infrastructure Development, 3, 2 (20I I): 153-I 70 
in the Hyderabad suburb where open areas and brushland were rapidly developed. The public open defecation sites were simply disappearing. Given these immediate and evenly-distributed pressures, it is surprising that only 44 per cent of women registered intent to construct a latrine, especially since sharing a household facility with neighbours is practically unheard of (interview with municipal official, 17 February 2010). Overall, it was apparent that mostly the better-off households (those with brick pukkah houses) would undertake the investment. The higher-rank women in the SHG Federations, who were tasked with educating SHG members specifically about the health benefits of sanitary latrines, repeatedly expressed their concern that the poorer members were excluded by the costs. The NGO employees also repeatedly made it clear that they did not expect being able to reach very poor households.

\section{Conclusion: Lessons from Two Very Different Cases}

This article has theoretically and empirically examined projects using microfinance for water and sanitation in developing countries. In Section 2, microfinance was introduced against the background of the changing transnational political economy of development since the 1980s. Section 3 explained the model of using microfinance for water and sanitation, critically examining the underlying assumptions and pointing out that the model requires households to recognise, internalise and capitalise the benefits privately. The underlying individualistic entrepreneurial approach based on an understanding of water and sanitation as private goods was criticised, and the collective action problems inherent in the supply of goods like water and sanitation were discussed. In Section 4, empirical evidence from two case study projects was presented: a field study conducted by Reis and Mollinga in Can Tho, Vietnam, and own fieldwork in Andhra Pradesh, India. Both projects operated in very different ways, but showed surprisingly similar problematic outcomes. This finding is discussed later, followed by a brief concluding note on further research and alternatives.

The empirical evidence from the cases in Vietnam and India calls into question a number of those presumptions made by advocates of microfinance for water and sanitation. While both projects showed some partial successes in generating new household water and sanitation access (which should by no means be discounted), both fell far short of their respective aims. A few differences in outcome should briefly be mentioned. The projects achieved a somewhat different scale, though not vastly dissimilar at 23,109 versus 5,613 total constructions implemented. Access to loan finance was constrained in Vietnam with respect to water purification systems, while problems with loan access were not found in India (perhaps a sign of the overheated microfinance market). Finally, insecurity of land use rights due to squatting or informality of settlements represented a reported problem for some households in India, but this was not reported in the case of Vietnam.

Yet despite the large differences in project design, their outcomes were remarkably similar. The fact that drinking water improvements ran into political interference from local elites in both cases - in the Vietnamese case because it went against their economic interests, and in the Indian case because it ran against embedded political interests and confronted caste identity issues - is a striking common outcome which was not predicted in the framework in Section 3 of this article. The projects' plans for improving drinking water access were very different, both technologically and in terms of governance, but access to drinking water was a highly contentious and politically embedded issue in both cases.

Journal of Infrastructure Development, 3, 2 (20I I): I53-I 70 
From a political viewpoint, the fact that local political institutions (which in India are democratic) may be bypassed and alienated, rather than strengthened, is of concern. While SHGs and their Federations in India apparently can act as viable institutions for the governance of social projects, it is important to prevent an inefficient and rivalrous process of parallel institution-building which would alienate existing local political institutions. More research will be needed to deepen an understanding of the interactions of such projects with the institutional environment, to determine whether these cases are unique or representative. Given the all-female SHGs, also a deeper analysis of the gendered dynamics is necessary.

A parallel finding linked to the local administrative system is that the public water providers of both places faced capacity problems in reaching the poor, albeit in different ways. In India, the irregular supply times and incapacity to arrange new network extensions were two serious problems. In both cases it was found that sewage networks were (mostly) out of the question, so that septic tanks, which may be less sanitary than piped sewage disposal, would have to be constructed. In both cases, the long-term sustainability question of emptying the tanks had not been sufficiently considered, which may lead to a profusion of unusable toilets in the future.

An interesting sociological finding was that health benefits or immediate financial gains were hardly ever reported as the key motivators for sanitation upgrading. These gains appear not to have been widely recognised, nor seen as internalisable or capitalisable. Instead, in Vietnam, the construction of a toilet was seen as a means to advance socially and/or gain status by upgrading one's house ('beautiful latrines'). In India, the main reported motivators were safety and privacy gains, alleviating the pressure of urbanisation. The usefulness of the latrine subsidy for housing extensions was observed in both cases, though no claim should be made that this usefulness diminished the sanitary gain. These findings draw into question the overall accuracy of the 'win-win' calculation made by microfinance advocates based on recognition, internalisation and capitalisation of financial gains. The individual gains households attained in both cases were largely non-financial and were mediated through societal norms.

In both cases, the actual costs of construction turned out to be considerably higher than the estimates of the projects' initiators, as reported by the households. Linked to this finding are concerns about equity which were raised in both cases, since mainly better-off families undertook the investments, while poorer families were usually unable to. While not particularly surprising, this issue should be taken very seriously. Normatively, it undermines the case for microfinance funding for water and sanitation from a fairness point of view, and operationally, diminished environmental and health impacts are likely if only part of the community is included - the merit goods aspect.

On the whole, it appears that microfinance for water and sanitation tackles symptoms instead of the causes underlying the underprovision of water and sanitation to the poor. These causes would have to be located in larger collective failures (no public capacity to provide), and unequal access ultimately stemming from inequitable social relations and an increasingly unequal ownership of the means of production. It can be seen that, much like the theory section of this article has argued, some important collective action problems and larger institutional failings existed in both cases, which the microfinance loans themselves cannot tackle. These include population pressures, environmental contamination, adverse climates (and climate change perhaps), perceptions of modernity and propriety, corruption and adverse business interests, local political opposition, insecure land rights, the incapacity or unwillingness of public providers to reach the poor, caste dynamics, and an inequitable distribution of resources. It almost appears as if the one element not missing was household's access to loan finance.

Journal of Infrastructure Development, 3, 2 (20I I): 153-I 70 
We should beware of an emergent micro-privatisation of public goods through microfinance, which would move their governance from the public realm into the sphere of private capital markets working through microfinance, and which could exacerbate many of the problems seen. Given the insight from economic theory that resources with public goods characteristics will be underprovided unless collective-action methods for their provision are found, the present lack of safe water and sanitation in poor communities is likely to result from too much market and too little public governance. As discussed above, the line between public and private goods is to a large extent socially constructed, so even if it were possible to extend water and sanitation using private loans, society may still choose to do otherwise. Making microfinance loans a determinant for water and sanitation access merely transfers the problem away from the political level (where it might be remedied in a socially just way) to the private level, where one's capacity to pay is the main determinant. It would institutionalise a situation of 'public provision for the rich, self-help for the poor'. To underscore this point, it should not be forgotten that the loan costs of microfinance-which even in India, a low-interest market, can exceed 60 per cent per annum (Shridhar 2010) - increase the price for water and sanitation improvements by the factor of interest. In this way, the concept of self-help via microfinance calls on the poor to pay even more than they would normally.

On a broader level, this contribution has left aside the normative implications of actually requiring the poor to pay for their access to water and sanitation, or indeed for any of the public goods with which they are underserved. But since 2002 there exists an internationally codified Human Right to Water under the International Covenant on Economic, Social and Cultural Rights (ICESCR) (ECOSOC 2003), which includes sanitation, and legal scholarship informs that '[c] ategorizing a right to water as a human right means that: fresh water is an entitlement, rather than a commodity or service provided on a charitable basis' (Bluemel 2004: 973). It should be clear then that projects which require the intended beneficiaries to take on debt detract from an unconditional right instead of fulfilling it. Alternatively, an approach based not on cost recovery from those least-suited to bear the costs, but rather on transfers, should be considered. As Rosemann (2005) has calculated, the Millennium Development Goal of water and sanitation is easily attainable: halving the number of people without access to water and sanitation in subSaharan Africa (for example) could be done with a grant of merely US $\$ 4.80$ per year from every person in the 15 countries of Western Europe.

\section{Notes}

1. The word institution is not used in the sociological sense. The usual terminology in development research of referring to those firms and NGOs which deal in microfinance as 'institutions', which is something of a misnomer as they are actually organisations, is adhered to for simplicity.

2. That Muhammad Yunus, modern microfinance's best-known spokesperson, founded or invented microfinance is a popular misconception.

3. The four largest donors posted a development assistance budget of 63,230 million US\$ in 2009 , contributing more than half of all DAC-registered foreign aid (OECD 2010). These budgets partially include loans to microfinance programmes. The qualifier at least is in place because MIX Market data is voluntarily reported by MFIs, representing the lion's share of the sector, but not all MFIs.

4. See Byström (2006).

Journal of Infrastructure Development, 3, 2 (20I I): I53-I 70 
5. Electricity: Kabir et al. (2010); irrigation: Muhammad (2005); health: Parker and Singh (2000), Pronyk et al. (2007), Dohn et al. (2004); education: Khumawala (2009), Leatherman and Dunford (2010); water and sanitation are dealt with further below.

6. RWSS $=$ Rural water supply and sanitation.

7. A case in point may be the WaterCredit programme run by the NGO water.org, which has made over 51,000 loans for water and sanitation in India, Bangladesh, Kenya and Uganda; see http://watercredit.org/about.

8. For basic sanitation, due to the use of simple and only partly hygienic systems such as pit latrines, there are fewer economies to scale; however, for advanced sanitary systems involving piping and centralised sewage treatment, the same applies as to water.

9. A (spoiler) caveat is in place here. In the Vietnam case, adverse business interests denied households the decision to invest in certain water treatment schemes, and in one town in the Indian case, no water supply was offered due to the system being inadequate.

10. Names and identity markers of the actors and people involved have been left out since some of the involved parties have stated their preference to remain anonymous.

11. $\mathrm{MEPMA}=$ Mission for the Elimination of Poverty in Urban Areas.

12. As one NGO worker explained to me, 'They prefer being famous for preventing something good than not to be having been involved in it' (interview, 24 June 2010).

13. For instance, water should not be placed in a certain corner of the house.

14. In one neighbourhood on the outskirts of Hyderabad, the tanker arrived while I was touring the neighbourhood. Women came running from houses in all directions with containers in order to secure their share of this water, as it was unclear when the next tanker would arrive.

\section{References}

Agbenorheri, M. and C. Fonseca (2005), 'Local Financing Mechanisms for Water Supply', WELL Briefing Note 16. Available online at http://www.lboro.ac.uk/well/resources/Publications/Briefing\%20Notes/BN16\%20Local\% 20financing.htm, accessed on 30 November 2010.

Arunachalam, Ramesh S. (2011), The Journey of Indian Micro-finance: Lessons for the Future. Chennai: Aapti Publications.

Bannerjee, A., E. Duflo, R. Glennerster and C. Kinnan (2009), 'The Miracle of Microfinance? Evidence from a Randomized Evaluation', first version. Available online at http://econ-www.mit.edu/files/4162, accessed on 30 November 2010.

Bateman, M. and H-J. Chang (2009), 'The Microfinance Illusion', mimeo., University of Juraj Dobrila Pula, Croatia, and University of Cambridge, UK. Available online at http://www.econ.cam.ac.uk/faculty/chang/pubs/ Microfinance.pdf, accessed on 29 November 2010.

Bateman, M. (2010), Why Doesn't Microfinance Work? London: Zed Books.

Bluemel, E. (2004), 'The Implications of Formulating a Human Right to Water', Ecology Law Quarterly, 31: 957-1006.

Byström, H. (2006), 'The Microfinance Collateralized Debt Obligation: A Modern Robin Hood?' Working Paper No. 14, Department of Economics, Lund University.

Davis, J., G. White, S. Damodaron and R. Thorsten (2008), 'Improving Access to Water Supply and Sanitation in Urban India: Microfinance for Water and Sanitation Infrastructure Development', Water Science and Technology, 58(4): 887-91.

Dohn, A., A. Chávez, M. Dohn, L. Saturria and C. Pimentel (2004), 'Changes in Health Indicators Related to Health Promotion and Microcredit Programs in the Dominican Republic', Revista Panamericana de Salud Pública, 15(3): 185-93.

Journal of Infrastructure Development, 3, 2 (20I I): 153-I 70 
Duvendack, M., R. Palmer-Jones, J.G. Copestake, L. Hooper, Y. Loke and N. Rao (2011), 'What Is the Evidence of the Impact of Microfinance on the Well-being of Poor People?' London: EPPI-Centre, Social Science Research Unit, Institute of Education, University of London. Available online at http://www.dfid.gov.uk/r4d/ SearchResearchDatabase.asp?OutputID $=187522$

ECOSOC (2003), 'The Right to Water' (Articles 11 and 12 of the International Covenant on Economic, Social and Cultural Rights). Available online at http://www.righttowater.info/code/General-Comment-15.pdf, accessed on 30 November 2010.

Gill, L. (2000), Teetering on the Rim. New York: Columbia University Press.

Gill, Stephen (1995), 'Globalization, Market Civilization, and Disciplinary Neoliberalism', Millennium: Journal of International Studies, 24(3): 399-423.

Gonzalez, Adrian (2010), Is Microfinance Growing Too Fast? Washington, DC: Microfinance Information Exchange (MIX). Available online at http://www.themix.org/sites/default/files/MIX\%20Data\%20Brief\%205\%20-\%20Is \%20microfinance\%20growing\%20too\%20fast.pdf, accessed on 27 November 2010.

Hall, David and Emanuele Lobina (2006), 'Water as a Public Service', Report Commissioned by Public Services International. London: PSIRU Business School, University of Greenwich.

Harvey, D. (1982), The Limits to Capital. Oxford: Blackwell.

Intellecap (2009), 'Flows: Filling up the Base of the Pyramid', Report Published by Intellecap. Available online at http://www.goodwell.nl/whatwedo/ FLOWS\%20REPORT\%20PHASE\%20I.pdf, accessed on 27 November 2010.

Kabir, M.A., H.S. Dey and H.M. Faraby (2010), 'Microfinance: The Sustainable Financing System for Electrification and Socio-economic Development of Remote Localities by Solar Home Systems (SHSs) in Bangladesh'. Paper presented at 4th Annual IEEE Systems Conference, San Diego. Available online at http://ieeexplore.ieee. org/xpl/freeabs_all.jsp?ar number=5482477, accessed on 24 November 2010.

Karlan, D. and J. Zinman (2009), 'Expanding Microenterprise Credit Access: Using Randomized Supply Decisions to Estimate the Impacts in Manila', Yale Economics Department Working Paper No. 68, Yale University Economic Growth Center Discussion Paper No. 976, Yale University.

Karnani, A. (2009), 'Romanticizing the Poor', Stanford Social Innovation Review, Winter: 38-43. Available online at http://www.scribd.com/doc/38018906/Romaticizing-the-Poor-Karnani, accessed on 22 November 2010.

Kaul, I. and R. Mendoza (2003), 'Advancing the Concept of Public Goods', in Inge Kaul, Pedro Conceição, Katell Le Goulven and Ronald U. Mendoza (eds), Providing Global Public Goods, pp. 78-111. New York: Oxford University Press.

Khumawala, S. (2009), ‘A Model for Microfinance-Supported Education Programs', Decision Line, January: 10-14. Available online at http://www. decisionsciences.org/decisionline/Vol40/40_1/dsi-dl40_1dean.pdf, accessed on 27 November 2010.

Leatherman, S. and C. Dunford (2010), 'Linking Health to Microfinance to Reduce Poverty', Bulletin of the World Health Organization, 88(6), June: 470-71.

Malkin, J. and A. Wildavsky (1991), 'Why the Traditional Distinction Between Public and Private Goods Should be Abandoned', Journal of Theoretical Politics, 3(4): 355-78.

Mehta, Meera (2008), 'Assessing Microfinance for Water and Sanitation: Exploring Opportunities for Scaling-Up'. Seattle: Bill and Melinda Gates Foundation.

Mehta, M. and A. Knapp (2004), 'The Challenge of Financing Sanitation for Meeting The Millennium Development Goals', Report for the 12th Session of the United Nations Commission on Sustainable Development (CSD-12), New York, 14-30 April.

Mehta, M., K. Virjee and S. Njoroge (2007), 'Helping a New Breed of Private Water Operators Access Infrastructure Finance', Gridlines, 25(May): 1-4, Public-Private Infrastructure Advisory Facility.

MIX Market (2009a), 'Microfinance at a Glance'. Available online at http://www.mixmarket.org/, accessed on 30 November 2010. 
MIX Market (2009b), 'Microfinance in India'. Available online at http://www. mixmarket.org/mfi/country/India, accessed on 24 November 2010.

Muhammad, L. (2005), 'Impact of Micro-finance on Terracing and Small-scale Irrigation in Sondu, Mogusi and Gucha River Catchment in South West Kenya'. Conference Paper from International Water Management Institute. Available online at http://econpapers.repec.org/RePEc:iwt:conppr: h037520, accessed on 24 November 2010.

OECD (2010), 'Statistical Annex of the 2010 Development Co-operation Report', Table 1. Available online at http:// www.oecd.org/dac/stats/dac/dcrannex, accessed on 27 November 2010.

Olivera, O. (2004), ;Cochabamba! Water War in Bolivia. New York: South End Press.

Parker, J. and I. Singh (2000), 'The Role of Microfinance in the Fight against HIV/AIDS', UNAIDS Background Paper, 15 September.

Pronyk, P., J. Hargreaves and J. Morduch (2007), 'Microfinance Programs and Better Health—Prospects for subSaharan Africa', Journal of the American Medical Association, 298(16): 1925-27.

Reis, N. and P. Mollinga (2009), 'Microcredit for Rural Water Supply and Sanitation in the Mekong Delta: Policy Implementation between the Needs for Clean Water and "Beautiful Latrines"', ZEF Working Paper 49. Bonn: Center for Development Research ZEF.

Rosemann, N. (2005), 'Financing the Human Right to Water as a Millennium Development Goal', Law, Social Justice \& Global Development Journal, 1. Available online at http://www.go.warwick.ac.uk/elj/lgd/2005_1/ rosemann, accessed on 30 November 2010.

Samuelson, P. (1954), 'The Pure Theory of Public Expenditure', The Review of Economics and Statistics, 36(4), November: $387-89$.

Servet, J.M. (2010), 'Indebtedness, the Pitfall of Microcredit'(draft). Paper presented at the American Anthropological Association Annual Meeting, November, New Orleans.

Shridhar, G. (2010), 'AP's Microfinance Institutions Admit to Charging up to 60.5\%', The Hindu, 30 October. Available online at http://www.thehindu businessline.com/2010/10/30/stories/2010103052310100.htm, accessed on 29 November 2010.

Taylor, Marcus (2011), "“Freedom from Poverty is Not for Free": Rural Development and the Microfinance Crisis in Andhra Pradesh, India', Journal of Agrarian Change, 11(4): 484-504.

Times of India (2010), ‘Another Bholakpur Waiting to Happen?', 20 April.

Turner, J. (1976), Housing by People: Towards Autonomy in Building Environments, Ideas in Progress. London: Marion Boyars.

Varley, R. (1995), 'Financial Services and Environmental Health: Household Credit for Water and Sanitation', EHP Applied Study No. 2. Arlington, VA.

Weber, Heloise (2006), 'The Global Political Economy of Microfinance and Poverty Reduction: Locating Local 'Livelihoods' in Political Analysis', in Jude L. Fernando (ed.), Microfinance: Perils and Prospects, pp. 37-54. London: Routledge.

Yunus, M. (2003), Banker to the Poor: Micro-Lending and the Battle against World Poverty. New York: Public Affairs.

Journal of Infrastructure Development, 3, 2 (20I I): I53-I 70 